\title{
ANALISIS SISTEM INVENTARISASI DAN PENILAIAN \\ BARANG MILIK DAERAH TERHADAP KUALITAS PENYAJIAN \\ LAPORAN KEUANGAN PEMERINTAH KOTA BEKASI
}

\author{
Rahmat Yuliansyah \\ Sekolah Tinggi Ilmu Ekonomi Indonesia \\ rahmaty6@gmail.com
}

\begin{abstract}
Abstak
The financial statements of the City of Bekasi examined by the Audit Board finances got opinions continued to increase from 2009 to 2015, with opinions as follows: (1) in 2009 - Disclaimer Opinion, (2) years of 2010-2014 Qualified Opinion; and the year 2015- Unqualified Opinion. Based on the Government Accounting Standards (SAP) No. 71 Year 2010 financial statements defines a structured report on the financial position and transactions undertaken by a reporting entity. Components financial statements consist of: (1) Report of the Budget consists of: (a) the Budget Realization Report (LRA) and (b) Statement of Changes in SAL. (2) Reports Financial consists of: (a) balance sheet, (b) Statements of Operations (LO), (c) Statement of Changes in Equity (LPE) (d) Statements of Cash Flows (LAK), and (e) Notes to the Financial Statements ( CaLK). Research data that has been collected and analyzed with the following methods: (1) reduction of the data is the data that has been collected is summarized, selected and focused on the data that is important and remove unnecessary data, making it easier for researchers to conduct gathering further data; (2) Data Presentation at present in the form of charts, tables or descriptions thorough on every aspect of the study; (3) The Decision concludes by describing the results of further data processing is summarized to then conclude the final results of the study.
\end{abstract}

Keywords: Regional Property, local government reports, opinion

\section{PENDAHULUAN}

\subsection{Latar Belakang Penelitian}

Pelaksanaan otonomi daerah berdasarkan UU No. 32 Tahun 2004 tentang Pemerintahan Daerah pasal 1 butir 5 memberi hak, wewenang, dan kewajiban kepada daerah otonom untuk mengatur dan mengurus sendiri urusan pemerintahan dan kepentingan masyarakat setempat sesuai dengan peraturan perundangundangan. Selanjutnya pada pasal 178 ayat (3) pemerintah daerah dalam pelaksanaan pengadaan barang dilakukan sesuai dengan kemampuan keuangan dan kebutuhan daerah berdasarkan prinsip efisiensi, efektivitas, dan transparansi dengan mengutamakan produk dalam negeri sesuai dengan peraturan perundang-undangan.

Pengelolaan barang milik daerah dilaksanakan berdasar pada PP No. 6 Tahun 2006 (Lembaran Negara RI tahun 2006 No.20, tambahan Lembaran Negara RI No. 
4609) kemudian diubah dengan PP No. 38 Tahun 2008 dan terakhir diubah degan PP No. 27 Tahun 2014 tentang Pengelolaan Barang Milik Negara/Daerah.

Guna mendukung pengelolaan barang milik daerah, Pemerintah Kota Bekasi berdasarkan Perda No. 5 Tahun 2010 membentuk Badan Pengelola Keuangan dan Aset Daerah (BPKAD) sebagai lembaga teknis yang mengelola keuangan dan aset daerah.

\section{Tabel 1.1}

Jenis aset yang dikelola oleh Pemerintah Kota Bekasi terdiri dari:

\begin{tabular}{|l|l|c|}
\hline No & \multicolumn{1}{|c|}{ Jenis Aset Tetap } & Nilai (Rp) \\
\hline 1 & Gedung dan Bangunan & $5.848 .084 .661,00$ \\
\hline 2 & Jalan, Jembatan, Irigasi dan Jaringan & $220.355 .057 .000,00$ \\
\hline 3 & Peralatan dan Mesin & $45.756 .698 .317,71$ \\
\hline 4 & Tanah & $100.748 .117 .750,00$ \\
\hline & Jumlah Aset Tetap & $372.707 .957 .728,71$ \\
\hline
\end{tabular}

Sumber: Badan Pengelola Keuangan Dan Aset Daerah Kota Bekasi

Pengelolaan aset Pemerintah Kota Bekasi dilaksanakan berdasarkan Perda No. 5 Tahun 2010 pasal 33 A dijelaskan BPKAD mempunyai tugas pokok melaksanakan penyusunan dan pelaksanaan kebijakan daerah di bidang anggaran, perbendaharaan, akuntansi dan aset.

Laporan keuangan Pemerintah Kota Bekasi yang diperiksa oleh Badan Pemeriksa Keuangan mendapat opini yang terus meningkat sejak tahun 2009 sampai dengan tahun 2015 sebagai berikut:

Tabel 1.2

Daftar Opini Badan Pemeriksa Keuangan

\begin{tabular}{|c|c|c|}
\hline Tahun & Opini & \multicolumn{1}{c|}{ Keterangan } \\
\hline 2009 & $\begin{array}{c}\text { Disclaimer Opinion } \\
\text { (Tidak Memberikan Pendapat) }\end{array}$ & $\begin{array}{c}\text { Terdapat selisih pembiayaan anggaran antara laporan } \\
\text { Pemerintah Kota Bekasi dengan temuan Komisi } \\
\text { Pemberantasan Korupsi (KPK) }\end{array}$ \\
\hline 2010 & $\begin{array}{c}\text { Qualified Opinion } \\
\text { (Wajar Dengan Pengecualian) }\end{array}$ & $\begin{array}{l}\text { Catatan pengecualian sbb: } \\
\text { (1) } 6 \text { (enam) point pada penyajian laporan keuangan, }\end{array}$ \\
& $\begin{array}{l}\text { (2) 13 (tiga belas) point pada sistem pengendalian } \\
\text { intern, dan }\end{array}$ \\
& $\begin{array}{l}\text { (3) } 15 \text { (lima belas) point pada kepatuhan terhadap } \\
\text { peraturan perundang-undangan }\end{array}$ \\
& $\begin{array}{l}\text { Dari semua yang dikecualikan (47,06\%) mengenai } \\
\text { manajemen pengelolaan aset daerah }\end{array}$ \\
\hline
\end{tabular}




\begin{tabular}{|c|c|c|}
\hline 2011 & $\begin{array}{c}\text { Qualified Opinion } \\
\text { (Wajar Dengan Pengecualian) }\end{array}$ & $\begin{array}{l}\text { Catatan } \quad \text { pengecualian } \\
\text { pertanggungjawaban dana BOS sekitar } 4,6 \\
\text { miliar masih belum sesuai dengan Petunjuk } \\
\text { teknis (juknis). }\end{array}$ \\
\hline 2012 & $\begin{array}{c}\text { Qualified Opinion } \\
\text { (Wajar Dengan Pengecualian }\end{array}$ & $\begin{array}{l}\text { Catatan pengecualian sbb: } \\
\text { (1) Pengelolaan fasos fasum, } \\
\text { (2) Aset tetap dan } \\
\text { (3) investasi non permanen. }\end{array}$ \\
\hline 2013 & $\begin{array}{c}\text { Qualified Opinion } \\
\text { (Wajar Dengan Pengecualian) }\end{array}$ & $\begin{array}{l}\text { Catatan pengecualian sbb: } \\
\text { Penatausahaan aset tetap }\end{array}$ \\
\hline 2014 & $\begin{array}{c}\text { Qualified Opinion } \\
\text { (Wajar Dengan Pengecualian) }\end{array}$ & $\begin{array}{l}\text { Catatan pengecualian sbb: } \\
\text { (1) Penatausahaan aset prasarana, sarana dan utilitas } \\
\text { (PSU/fasos) } \\
\text { (2) Temuan dana Rp.137 Miliar belum diverifikasi } \\
\text { (3) Pencatatan piutang pajak } \\
\text { (4) Pencatatan aset dana BOS dari Pusat tanpa } \\
\text { inventarisasi }\end{array}$ \\
\hline 2015 & $\begin{array}{c}\text { Unqualified Opinion } \\
\text { (Wajar Tanpa Pengecualian) }\end{array}$ & \\
\hline
\end{tabular}

Sumber: Badan Pengelola Keuangan Dan Aset Daerah Kota Bekasi

Berdasarkan opini yang diterima Pemerintah Kota Bekasi dari hasil pemeriksaan BPK sejak tahun 2009 sampai dengan tahun 2015, terjadi peningkatan dalam kualitas opini terhadap penyajian laporan keuangan. Dari tabel diatas terlihat opini yang diperoleh pada tahun 2009 disclaimer opinion. BPK tidak memberikan pendapat terhadap laporan yang disajikan Pemerintah Kota Bekasi. Hal ini terjadi karena terdapat selisih pembiayaan anggaran antara laporan Pemerintah Kota Bekasi dengan temuan Komisi Pemberantasan Korupsi (KPK)

Selanjutnya selama 5 tahun berturut-turut opini yang di capai Pemerintah Kota Bekasi Unqualified Opinion (Wajar Dengan Pengecualian). Untuk memperoleh kualitas opini yang optimal Pemerintah Kota Bekasi terus berusaha menyusun pertanggungjawabannya, sehingga pada tahun 2016 Pemerintah Kota Bekasi berhasil memperoleh pendapat Wajar Tanpa Pengecualian (Unqualified Opinion) terhadap penyajian laporan keuangan periode 2015.

\subsection{Spesifikasi Masalah Pokok Penelitian}

Berdasarkan perumusan masalah pokok penelitian di atas, maka masalah penelitian dapat dispesifikasikan sebagai berikut:

1. Apakah yang telah dilakukan Pemerintah Kota Bekasi dalam menertibkan pengelolaan BMD? 
2. Kebijakan apa yang dilakukan oleh Pemerintah Kota Bekasi dalam mengatasi masalah-masalah yang timbul dalam pelaksanaan Pengelolaan BMD?

3. Bagaimana tindak lanjut dari hasil penertiban pengelolaan BMD?

4. Bagaimana pengaruh hasil pelaksanaan penertiban pengelolaan BMD terhadap laporan keuangan dan kualitas Opini BPK?

Dari pertanyaan-pertanyaan ini peneliti akan mencoba meneliti jawabannya melalui pengumpulan dan analisis data penelitian.

\subsection{Perumusan Masalah Pokok Penelitian}

Masalah utama yang akan dikaji dalam penelitian ini berdasarkan opini BPK terhadap pengecualian dari hasil pemeriksaan laporan keuangan Pemerintah Kota Bekasi. Pengecualian BPK menyatakan WDP dengan pengecualian terhadap manajemen pengelolaan aset daerah berturut-turut selama 5 tahun. Untuk itu, BPKAD sebagai pengelola aset-aset Pemerintah Kota Bekasi melakukan penertiban terhadap pengelolaan Barang Milik Daerah. Pada tahun 2016 Pemerintah Kota Bekasi mendapat opini Wajar Tanpa Pengecualian dari BPK terhadap Laporan Keuangan tahun 2015. Sehingga dapat diambil rumusan masalah pokok penelitian sebagai berikut:

"Bagaimana Badan Pengelola keuangan dan Aset Dearah Pemerintah Kota Bekasi melaksanakan Inventarisasi dan Penilaian BMD serta analisis dan kontribusinya terhadap penyajian laporan keuangan dan kualitas Opini BPK?”.

\subsection{Batasan Masalah}

Apabila dirangkum dari berbagai penjelasan di atas, dapat diidentifikasikan beberapa permasalahan yang terjadi untuk dijadikan sebagai bahan penelitian sebagai berikut:

1. Sampai dengan tahun 2014 Badan Pemeriksa Keuangan (BPK) masih menemukan penyimpangan pengelolaan manajemen aset sebesar 35\% dari seluruh cakupan aset yang diaudit;

2. Temuan pemeriksaan manajemen aset terutama berkaitan dengan permasalahan administrasi atau pencatatan, dan bukti yang sah atas aset yang dikuasai yang berdampak pada kewajaran penyajian nilai aset dalam laporan keuangan, rawan 
terhadap penyalahgunaan, pengakuan hak oleh pihak lain, dan sengketa di kemudian hari yang pada akhirnya dapat merugikan negara atau daerah;

3. Terdapat tiga belas point kelemahan dalam implementasi Sistem Pengendalian Intern pada Laporan Keuangan Pemerintah Kota Bekasi;

4. Sebagai langkah pembenahan sejak laporan keuangan dinyatakan disclaimer oleh BPK, maka Pemerintah Kota Bekasi dalam hal ini BPKAD melakukan penertiban atas aset-aset milik daerah yang berlangsung selama 5 tahun;

5. Faktor-faktor yang memperlambat pelaksanaan Penertiban diantaranya kurang tertibnya administrasi, kurangnya pemahaman terhadap aturan, serta kemampuan SDM kurang;

6. Penertiban barang milik negara meliputi kegiatan inventarisasi, penilaian, dan sertifikasi aset negara;

7. Tahun 2016 BPK memberikan opini Wajar Tanpa Pengecualian (WTP/Unqualified Opinion) kepada Pemerintah Kota Bekasi atas laporan keuangan tahun 2015.

\subsection{Tujuan Penelitian}

Penelitian ini dilakukan dengan tujuan untuk: mengetahui bagaimana Badan Pengelola keuangan dan Aset Dearah Pemerintah Kota Bekasi melaksanakan inventarisasi dan penilaian BMD serta analisis dan kontribusinya terhadap penyajian laporan keuangan dan kualitas Opini BPK.

\subsection{Kegunaan Penelitian}

Penelitian ini diharapkan dapat memberikan manfaat sebagai berikut:

1. Bagi Pengembangan Keilmuan

Sebagai sumbangsih penting dan memperluas kajian ilmu akuntansi pemerintahan yang menyangkut pengelolaan BMD

2. Bagi Pihak BPKAD

Sebagai sumbangsih pemikiran bagi pimpinan BPKAD untuk meningkatkan kualitas pengelolaan kekayaan daerah yang diharapkan dapat mempertahankan kualitas opini BPK terhadap laporan keuangan.

3. Bagi Masyarakat 
Khususnya bagi pegawai dan pengelola BMD di BPKAD diharapkan dapat melakukan pengelolaan kekayaan daerah yang menjadi kewenangannya semaksimal mungkin.

\section{Landasan Teori}

\subsection{Pengertian Inventarisasi}

Kata inventarisasi berdasarkan KBBI (http://kbbi.web.id/inventarisasi) berarti pencatatan atau pendaftaran barang-barang milik kantor, (sekolah, rumah tangga, dan sebagainya) yang dipakai dalammelaksanakan tugas. Pencatatan atau pengumpulan data (tentang kegiatan, hasil yang dicapai, pendapat umum, persuratkabaran, kebudayaan, dan sebagainya)

\subsection{Pengertian Penilaian}

Kata inventarisasi berdasarkan KBBI (http://kbbi.web.id/inventarisasi) berarti proses, cara, perbuatan menilai, pemberian nilai (biji, kadar mutu, harga).

\subsection{Barang Milik Daerah}

Pengelolaan barang milik daerah dilaksanakan berdasar pada PP No. 6 Tahun 2006 (Lembaran Negara RI tahun 2006 No.20, tambahan Lembaran Negara RI No. 4609) kemudian diubah dengan PP No. 38 Tahun 2008 dan terakhir diubah degan PP No. 27 Tahun 2014 tentang Pengelolaan Barang Milik Negara/Daerah.

Pasal 1 butir 2 PP No. 27 Tahun 2014 tentang Pengelolaan Barang Milik Negara/Daerah dijelaskan Barang Milik Daerah adalah semua barang yang dibeli atau diperoleh atas beban Anggaran Pendapatan dan Belanja Daerah atau berasal dari perolehan lainnya yang sah

Selanjutnya UU No. 1 Tahun 2004 tentang Perbendaharaan Negara bab IV yang mengatur pengelolaan barang milik negara/daerah pasal 42 dijelaskan (1) Menteri Keuangan mengatur pengelolaan barang milik negara. (2) Menteri/pimpinan lembaga adalah Pengguna Barang bagi kementerian negara/lembaga yang dipimpinnya. (3) Kepala kantor dalam lingkungan kementerian negara/lembaga adalah Kuasa Pengguna Barang dalam lingkungan kantor yang bersangkutan.

Selanjutnya pasal 43 (1) Gubernur/bupati/walikota menetapkan kebijakan pengelolaan barang milik daerah. (2) Kepala Satuan Kerja Pengelola Keuangan Daerah melakukan pengawasan atas penyelenggaraan pengelolaan barang milik daerah sesuai dengan kebijakan yang ditetapkan oleh gubernur/bupati/walikota. (3) 
Kepala satuan kerja perangkat daerah adalah Pengguna Barang bagi satuan kerja perangkat daerah yang dipimpinnya. Pasal 44 Pengguna Barang dan/atau Kuasa Pengguna Barang wajib mengelola dan menatausahakan barang milik negara/daerah yang berada dalam penguasaannya dengan sebaik-baiknya. Selanjutnya pasal 49 menjelaskan (1) Barang milik negara/daerah yang berupa tanah yang dikuasai Pemerintah Pusat/Daerah harus disertifikatkan atas nama pemerintah Republik Indonesia/pemerintah daerah yang bersangkutan. (2) Bangunan milik negara/daerah harus dilengkapi dengan bukti status kepemilikan dan ditatausahakan secara tertib. (3) Tanah dan bangunan milik negara/daerah yang tidak dimanfaatkan untuk kepentingan penyelenggaraan tugas pokok dan fungsi instansi yang bersangkutan, wajib diserahkan pemanfaatannya kepada Menteri Keuangan/ gubernur/bupati/ walikota untuk kepentingan penyelenggaraan tugas pemerintahan negara/daerah.

Barang milik negara/daerah yang dikelola pemerintah berupa aset yang berdasarkan Kerangka Konseptual Akuntansi Pemerintahan paragraf 62 diklasifikasikan ke dalam aset lancar dan non lancar. Suatu aset diklasifikasikan sebagai aset lancar jika diharapkan segera untuk dapat direalisasikan atau dimiliki untuk dipakai atau dijual dalam waktu 12 bulan sejak tanggal pelaporan. Aset yang yang tidak dapat dimasukkan dalam kriteria tersebut diklasifikasikan sebagai aset nonlancar.

PSAP 01 paragraf 50 mendefinisikan aset nonlancar mencakup aset yang bersifat jangka panjang dan aset tak berwujud, yang digunakan secara langsung atau tidak langsung untuk kegiatan pemerintah atau yang digunakan masyarakat umum.

PSAP Nomor 7 paragraf 8 mengklasifikasikan aset tetap berdasarkan kesamaan dalam sifat atau fungsinya dalam aktifitas operasi entitas. Berikut adalah klasifikasi aset tetap yang digunakan: (a) Tanah (b) Peralatan dan Mesin (c) Gedung dan Bangunan (d) Jalan, Irigasi dan Jaringan (e) Aset Tetap Lainnya (f) Konstruksi Dalam Pengerjaan. Selanjutnya paragraf 9 -15 mendefinisikan masing-masing aset tetap sebagai berikut: 
a. Tanah yang dikelompokkan sebagai aset tetap ialah tanah yang diperoleh dengan maksud untuk dipakai dalam kegiatan operasional pemerintah daerah dan dalam kondisi siap dipakai.

b. Peralatan dan mesin mencakup mesin-mesin dan kendaraan bermotor, alat elektonik, inventaris kantor, dan peralatan lainnya yang nilainya signifikan, masa manfaatnya lebih dari 12 bulan, dan dalam kondisi siap pakai.

c. Gedung dan bangunan mencakup seluruh gedung dan bangunan yang diperoleh dengan maksud untuk dipakai dalam kegiatan operasional pemerintah daerah dan dalam kondisi siap dipakai.

d. Jalan, irigasi, dan jaringan mencakup jalan, irigasi, dan jaringan yang dimiliki dan/atau dikuasai oleh pemerintah daerah; dan dalam kondisi siap dipakai.

e. Aset tetap lainnya mencakup aset tetap yang tidak dapat dikelompokkan ke dalam kelompok aset tetap di atas, yang diperoleh dan dimanfaatkan untuk kegiatan operasional pemerintah daerah dan dalam kondisi siap dipakai.

f. Konstruksi dalam pengerjaan mencakup aset tetap yang sedang dalam proses pembangunan yang pada tanggal laporan keuangan belum selesai seluruhnya.

Dari definisi diatas dijelaskan bahwa barang milik daerah diklasifikasikan dalam kelompok aset tidak lancar yang terdiri dari aset yang bersifat jangka panjang terdri dari: (a) Tanah (b) Peralatan dan Mesin (c) Gedung dan Bangunan (d) Jalan, Irigasi dan Jaringan (e) Aset Tetap Lainnya (f) Konstruksi Dalam Pengerjaan. Aset tak berwujud pada paragraf 60 PSAP 1 menjelaskan aset nonlancar lainnya diklasifikasikan sebagai aset lainnya. Termasuk dalam aset lainnya adalah aset tak berwujud, tagihan penjualan angsuran yang jatuh tempo lebih dari 12 bulan dan aset kerjasama dengn fihak ketiga (kemitraan).

Pengukuran aset tetap dengan melakukan penilaian aset tetap berdasarkan biaya perolehan dan jika tidak memungkinkan maka aset tetap dinilai berdasarkan nilai wajar pada saat perolehan.

PSAP 7 paragraf 29 Komponen biaya perolehan aset tetap terdiri dari harga beli atau konstruksinya, termasuk bea impordan setiapp biaya yang dapat diatribusikan secara langsung dalam membawa aset tersebut ke kondisi yang membuat aset tersebut dapat bekerja untuk penggunaan yang dimaksudkan.

Biaya yang dapat diatribusikan secara langsung adalah: (a) biaya persiapan tempat (b) biaya pengiriman awal (initial delivery) dan biaya simpan dan bongkar muat (handling 
cost) (c) biaya pemasangan (instalation cost) (d) biaya profesional seperti arsitek dan insinyur dan (e) biaya konstruksi.

Kontruksi dalam pengerjaan, jika penyelesaian pengerjaannya lebih atau melewati satu periode tahun anggaran, maka aset tetap tersebut digolongkan dan dilaporkan sebagai konstruksi dalam pengerjaan sampai dengan aset tersebut selesai dan siap dipakai

Aset yang diperoleh sacara gabungan biaya perolehannya ditentukan dengan mengalokasikan harga gabungan berdasarkan perbandingan nilai wajar masing-masing aset bersangkutan.

Pertukaran aset tetap diukur berdasarkan nilai wajar perolehannya,yaitu nilai ekuivalen atas nilai tercatat aset tetap yang dilepas setelah disesuaikan dengan jumlah setiap kas atau setara kas yang ditransfer/diserahkan.

Aset yang berasal dari donasi (sumbangan)harus dicatat sebesar nilai wajar saat perolehan.

Pengeluaran setelah perolehan awal suatu asset tetap yang memperpanjang masa manfaat atau yang kemungkinan besar memberi manfaat ekonomik di masa yang akan datang dalam bentuk kapasitas, mutu produksi atau peningkatan standar kinerja, harus ditambahkan pada nilai tercatat aset yang bersangkutan.

Dari definisi tersebut, terdapat beberapa kriteria suatu aset dapat klasifikasikan sebagai aset tetap, yaitu (1) mempunyai masa manfaat lebih dari 12 bulan, (2) biaya perolehan aset dapat diukur secara andal, (3) bukan untuk dijual dalam kegiatan normal entitas, dan (5) diperoleh atau dibangun untuk digunakan dalam operasional.

\subsection{PENYUSUTAN}

Pada Standar Akuntansi Pemerintah berbasis akrual berdasarkan PP RI NO. 71 TAHUN 2010 pernyataan 1 menjelaskan penyusutan adalah alokasi yang sistematis atas nilai suatu aset tetap yang dapat disusutkan (depreciable assets) selama masa manfaat aset yang bersangkutan.

Dalam kerangka konseptual Standar Akuntansi Pemerintah di jelaskan Penyusutan aset tetap merupakan, aset yang digunakan pemerintah, kecuali beberapa jenis aset tertentu seperti tanah, mempunyai masa manfaat dan kapasitas yang terbatas. Seiring dengan penurunan kapasitas dan manfaat dari suatu aset dilakukan penyesuaian nilai.

PSAP 7 menjelaskan nilai penyusutan untuk masing-masing periode diakui sebagai pengurang nilai tercatat aset tetap dalam neraca dan beban penyusutan dalam 
laporan operasional. Penyesuaian nilai aset tetap dilakukan dengan berbagai metode yang sistematis sesuai dengan masa manfaat. Metode penyusutan yang digunakan harus dapat menggambarkan manfaat ekonomi atau kemungkinan jasa (service potential) yang akan mengalir ke pemerintah.

Masa manfaat aset tetap yang dapat disusutkan harus ditinjau secara periodik dan jika terdapat perbedaan besar dari estimasi sebelumnya, penyusutan periode sekarang dan yang akan datang harus dilakukan penyesuaian.

Metode penyusutan yang dapat dipergunakan antara lain:

(a) Metode garis lurus (straight line method)

Beban penyusutan menurut metode ini dihitung sebagai berikut:

$$
\begin{array}{cl}
\mathbf{D}=\underline{\mathbf{C}-\mathbf{S}} & \mathrm{D}=\text { Beban penyusutan } \\
\mathbf{n} & \mathrm{C}=\text { Harga pokok aset } \\
& \mathrm{S}=\text { Nilai residu } \\
& \mathrm{n}=\text { Umur teknis }
\end{array}
$$

(b) Metode saldo menurun Ganda (doub declining balance method)

Beban penyusutan dihitung mengabaikan/tanpa mengurangi nilai sisa dari harga perolehannya. Beban penyusutan dihitung dengan menggunakan prosentase dikali nilai bukunya. Beban penyusutan setiap periode akan berbeda, sesuai dengan perkalian nilai buku masing-masing. Prosentase diperhitungkan $2 \mathrm{x}$ metode garis lurus:

$$
\text { Rumus Perhitungan Prosentase }=\frac{100 \%}{\text { Masa Manfaat }}
$$

\section{Rumus Perhitungan Beban Penyusutan}

$$
\text { Beban Penyusutan }=\text { Prosentase } \mathrm{x} \text { Nilai Buku }
$$

(c) Metode unit produksi (unit of production method)

Beban penyusutan dihitung berdasarkan penetapan tarif dari harga perolehan aktiva tetap dikurangi nilai sisanya kemudian dibagi dengan perkiraan total produksi keseluruhan. Tarif tersebut dikalikan hasil produksi periode yang bersangkutan. Rumus Perhitungan Tarif:

$$
\text { Tarif }=\quad \text { Harga Perolehan }- \text { Nilai Sisa }
$$




\section{Perkiraan Total Produksi}

Rumus Perhitungan Beban Penyusutan:

Beban Penyusutan $=$ Tarif $\mathrm{x}$ Jumlah unit produksi periode bersangkutan

\subsection{Laporan Keuangan}

Penyajian laporan keuangan sebagai bagian pengelolaan keuangan perusahaan/organisasi sering disebut sebagai akhir dari proses akuntansi. Laporan keuangan menyajikan data terkait kondisi keuangan perusahaan/organisasi yang digunakan pihak berkepentingan untuk pengambilan keputusan.

Pengertian laporan keuangan menurut Ikatan Akuntan Indonesia dalam Standar Akuntansi Keuangan (2010:1) mengemukakan bahwa,

Laporan keuangan merupakan bagian dari proses pelaporan keuangan. Laporan keuangan yang lengkap biasanya meliputi neraca, laporan laba rugi, laporan perubahan posisi keuangan (yang dapat disajikan dalam berbagai cara misalnya, sebagai laporan arus kas, atau laporan arus dana), catatan dan laporan lain serta materi penjelasan yang merupakan bagian integral dari laporan keuangan. Di samping itu juga termasuk skedul dan informasi tambahan yang berkaitan dengan laporan tersebut, misalnya, informasi keuangan segmen industri dan geografis serta pengungkapan pengaruh perubahan harga.

Selanjutnya Harahap (2002:7) mengemukakan bahwa,

Laporan keuangan adalah merupakan pokok atau hasil akhir dari suatu proses akuntansi. Laporan keuangan inilah yang menjadi bahan informasi bagi para pemakainya sebagai salah satu bahan dalam proses pengambilan keputusan. Di samping sebagai informasi, laporan keuangan juga sebagai pertanggungjawaban atau accountability. Dan juga dapat menggambarkan indikator kesuksesan suatu perusahaan mencapai tujuannya.

Berdasarkan defenisi tersebut, laporan keuangan merupakan hasil dari proses akuntansi terkait transaksi dari kegiatan usaha perusahaan pada periode tertentu. Laporan keuangan sebagai pertanggungjawaban sekaligus informasi pengelola/manajemen perusahaan/organisasi kepada pihak intern dan pihak ekstern yang meliputi investor, pemilik perusahaan, karyawan, pemberi pinjaman (kreditor), pemasok, pelanggan, pemerintah, masyarakat dan pengguna lainnya sebagai dasar pengambilan keputusan. Laporan keuangan merupakan bukan hasil akhir tetapi sebagai alat dalam mengkomunikasikan data keuangan atau kegiatan yang menjadi tujuan penyajian laporan keuangan. 


\subsubsection{Laporan Keuangan Pemerintah Daerah}

Berdasarkan Standar Akuntansi Pemerintah (SAP) No. 24 Tahun 2005 pada PSAP 1 paragraf 9 mendefinisikan laporan keuangan merupakan laporan yang terstruktur mengenai posisi keuangan dan transaksi-transaksi yang dilakukan oleh suatu entitas pelapor. Tujuan umulaporan keuangan adalah menyajikan informasi mengenai posisi keuangan, realisasi anggaran, arus kas dan kinerja keuangan suatu entitas peleporan yang bermanfaat bagi para pengguna dalam membuat dan mengevaluasi keputusan mengenai alokasi sumber daya.

Peraturan Pemerintah Nomor 71 Tahun 2010, laporan keuangan merupakan laporan yang terstruktur mengenai posisi keuangan dan transaksi-transaksi yang dilakukan oleh suatu entitas. Secara umum tujuan laporan keuangan pemerintah untuk menyajikan informasi yang berguna dalam pengambilan keputusan dan untuk menunjukkan akuntabilitas entitas atas pengelolaan sumber daya perusahaan/organisasi. PP No. 71 Tahun 2010 menjelaskan kompenen laporan keuangan terdiri dari:

1. Laporan Pelaksanaan Anggaran terdiri dari :
(a) Laporan Realisasi Anggaran (LRA) dan
(b) Laporan Perubahan SAL.

2. Laporan Finansial terdiri dari :
(a) Neraca,
(b) Laporan Operasional (LO),
(c) Laporan Perubahan Ekuitas (LPE)
(d) Laporan Arus Kas (LAK), dan
(e) Catatan Atas Laporan Keuangan (CALK)

Laporan Perubahan SAL dan Laporan Arus Kas (LAK) hanya disajikan oleh entitas yang mempunyai fungsi perbendaharaan umum, dalam hal ini Pemerintah daerah sebagai entitas pelaporan

\section{Laporan Realisasi Anggaran}

Laporan Realisasi Anggaran (LRA) merupakan laporan pelaksanaan anggaran yang menggambarkan perbandingan antara anggaran dengan realisasinya 
dalam satu periode pelaporan. Informasi LRA berguna bagi dalam mengevaluasi keputusan alokasi sumber-sumber daya ekonomi, akuntabilitas dan ketaatan entitas terhadap anggaran. Dari LRA dapat dilihat tingkat penyerapan anggaran entitas yang dapat menjadi salah satu indikator produktivitas atau kinerja entitas. LRA disusun dan disajikan dengan menggunakan basis kas.

\section{Laporan Perubahan Saldo Anggaran Lebih}

Laporan Perubahan Saldo Anggaran Lebih menyajikan informasi kenaikan atau penurunan Saldo Anggaran Lebih tahun pelaporan dibandingkan dengan tahun sebelumnya.

3. Neraca

Neraca menggambarkan posisi keuangan suatu entitas pelaporan mengenai aset, kewajiban, dan ekuitas pada tanggal tertentu.

\section{Laporan Operasional}

Laporan Operasional menyajikan ikhtisar sumber daya ekonomi yang menambah ekuitas dan penggunaannya yang dikelola oleh pemerintah pusat/daerah untuk kegiatan penyelenggaraan pemerintahan dalam satu periode pelaporan.

\section{Laporan Arus Kas}

Laporan Arus Kas menyajikan informasi kas sehubungan dengan aktivitas operasi, investasi, pendanaan, dan transitoris yang menggambarkan saldo awal, penerimaan, pengeluaran, dan saldo akhir kas pemerintah pusat/daerah selama periode tertentu.

\section{Laporan Perubahan Ekuitas}

Laporan Perubahan Ekuitas menyajikan informasi kenaikan atau penurunan ekuitas tahun pelaporan dibandingkan dengan tahun sebelumnya.

\section{Catatan atas Laporan Keuangan}

Catatan atas Laporan Keuangan (CaLK) meliputi penjelasan naratif atau rincian dari angka yang tertera dalam Laporan Realisasi Anggaran, Laporan Perubahan SAL, Laporan Operasional, Laporan Perubahan Ekuitas, Neraca, dan Laporan Arus Kas. CaLK juga mencakup informasi tentang kebijakan akuntansi yang dipergunakan oleh entitas pelaporan dan informasi lain yang diharuskan dan dianjurkan untuk diungkapkan di dalam Standar Akuntansi Pemerintahan serta 
ungkapan-ungkapan yang diperlukan untuk menghasilkan penyajian laporan keuangan secara wajar.

\subsubsection{Kualitas Laporan Keuangan Pemerintah Daerah}

Laporan keuangan merupakan informasi yang mengkomunikasikan data keuangan kepada pihak internal maupun pihak eksternal yang berkepentingan /membutuhkan laporan kegiatan perusahaan/organisasi. Laporan keuangan pemerintah daerah sesuai dengan UU No. 17 Tahun 2003 tentang Keuangan Negara pasal 31 menjelaskan ayat (1) Gubernur/Bupati/Walikota menyampaikan rancangan peraturan daerah tentang pertanggungjawaban pelaksanaan APBD kepada DPRD berupa laporan keuangan yang telah diperiksa oleh Badan Pemeriksa Keuangan, selambat-lambatnya 6 (enam) bulan setelah tahun anggaran berakhir. Ayat (2) Laporan keuangan dimaksud setidak-tidaknya meliputi Laporan Realisasi APBD, Neraca, Laporan Arus Kas, dan Catatan atas Laporan Keuangan, yang dilampiri dengan laporan keuangan perusahaan daerah.

Berdasarkan penjelasan tersebut pemerintah daerah sebagai pelaksana anggaran wajib menyajikan laporan keuangan yang disampaikan kepada DPRD setelah diperiksa oleh BPK. Pemeriksaan yang dilakukan oleh BPK terhadap laporan keuangan pemerintah daerah bertujuan untuk menghasilkan opini (pendapat) terhadap kualitas laporan keuangan tersebut. Opini terhadap pemeriksaan (audit) laparan keuangan terdir dari : (1) Wajar Tanpa Pengecualian (Unqualified Opinion), (2) Wajar dengan Pengecualian (Qualified Opinion), (3) Tidak Wajar (Adverse Opinion), dan (4) Tidak Memberikan Pendapat (Disclaimer Opinion).

1. Opini WTP (Wajar Tanpa Pengecualian/Unqualified Opinion) diberikan oleh BPK terhadap LKPD yang dengan kriteria: (1) Laporan keuangan yang disajikan telah sesuai dengan Standar Akuntansi Pemeintah (SAP), (2) Sistem Pengendalian Intern (SPI) terhadap pengelolaan keuangan daerah telah dilaksanakan dengan baik, dan (3) Kepatuhan terhadap peraturan perundangundangan yang berlaku. Selain itu yang sangat mendasar penyajian LKPD harus didukung bukti-bukti transaksi yang mencukupi sebagai dasar audit, tidak terdapat ketidakpastian dan kesalahan yang cukup berarti (no material 
uncertainties), Cash flow dikelola dan diawasi dengan baik, dan aset daerah yang dikelola dilengkapi dengan bukti-bukti administrasi. WTP akan di capai jika, laporan keuangan yang disajikan bebas dari kesalahan atau kekeliruan yang material.

2. Opini WDP (Wajar Dengan Pengecualian/Qualified Opinion) diberikan BPK terhadap LKPD jika dalam penyajian laporan keuangan tersebut masih terdapat kekeliruan, namun kesalahan atau kekeliruan tersebut secara keseluruhan tidak mempengaruhi kewajaran laporan keuangan.

3. Opini Tidak Wajar (Adverse Opinion) diberikan BPK terhadap LKPD yang disajikan mengandung banyak sekali kesalahan atau kekeliruan yang bersifat material dimana laporan keuangan yang disajikan tidak menggambarkan kondisi keuangan secara benar.

4. Opini Tidak Memberikan Pendapat (Disclaimer Opinion). Pendapat ini diberikan karena hal berikut: (1) Ruang lingkup audit dibatasi. Dalam hal ini auditor tidak berhasil mengumpulkan bukti audit yang mencukupi sebagai dasar keputusan pemberian opini dari laporan keuangan yang diperiksanya Laporan keuangan yang diperiksa tidak sesuai dengan prinsip akuntansi yang berlaku umum di Indonesia. (3) Prinsip akuntansi tidak diterapkan secara konsisten dlam penyajian laporan keuangan. (4) Terdapat ketidakpastian material yang mempengaruhi laporan keuangan dan kelanjutannya dalam laporan yang di audit. (5) Auditor tidak independen.

\section{PROSEDUR PENELITIAN}

\subsection{Lokasi dan Waktu Penelitian}

Penelitian terkait aktivitas pengumpulan data dilakukan pada Badan Pengelola Keuangan Dan Aset Daerah (BPKAD) yang beralamat di Jl. Jenderal Ahmad Yani No. 1 Kota Bekasi. Waktu penelitian dilakukan selama 6 bulan sejak pertengahan Januari sampai dengan pertengahan Juli 2016. 


\subsection{Metode Penelitian}

Penelitian ini termasuk kategori penelitian terapan (applied research) yang secara spesifik ditujukan untuk mengidentifikasi permasalahan seputar langkahlangkah yang diambil oleh DJKN dalam melaksanakan penertiban BMN serta kontribusi penertiban BMN kepada kualitas opini BPK terhadap LKPP. Selanjutnya melalui penelitian ini diharapkan pula dapat diusulkan berbagai bentuk perbaikan kegiatan pengelolaan BMN untuk dapat memaksimalkan kekayaan negara yang ada. Oleh karena itu, dalam konteks sebagai penelitian terapan, penelitian ini termasuk penelitian tindakan (action research).

Berdasarkan karakteristik masalah pokok penelitiannya, strategi yang tepat untuk penelitian ini adalah yang bersifat studi kasus. Artinya, penelitian ini dilakukan dengan tujuan untuk mendapatkan gambaran dan penjelasan yang lengkap dan mendalam nengenai langkah-langkah yang pernah dilakukan DJKN dalam melaksanakan penertiban BMN, dan berbagai rekomendasi terkait langkahlangkah baru yang dipandang cukup efektif untuk memaksimalkan pengelolaan kekayaan negara.

\subsection{Metode Pengumpulan Data}

Metode pengumpulan data yang akan digunakan dalam penelitian ini adalah metode riset kepustakaan dari berbagai buku literatur yang berkaitan. Selain itu, penulis juga menggunakan data primer di peroleh dari BPKAD Kota Bekasi maupun sekunder yang diambil dari sumber publik seperti jurnal, laporan dan media cetak.

\subsection{Metode Analisis Data}

Data-data penelitian yang telah dikumpulkan dianalisis dengan metode sebagai berikut:

\section{Reduksi Data}

Pada tahap ini data yang telah terkumpul dirangkum, dipilih dan difokuskan pada data-data yang penting serta membuang data yang tidak perlu, sehingga mempermudah peneliti untuk melakukan mengumpulan data selanjutnya;

2. Penyajian Data 
Untuk memudahkan dalam membahas data yang diperoleh, maka data yang telah direduksi tersebut kemudian disajikan dalam bentuk grafik, tabel atau deskripsi yang menyeluruh pada setiap aspek yang diteliti;

3. Pengambilan kesimpulan

Deskripsi dan hasil pengolahan data selanjutnya dirangkum untuk kemudian simpulkan sebagai hasil akhir penelitian.

\section{HASIL-HASIL PENELITIAN}

\subsection{Gambaran Umum}

\subsubsection{Gambaran umum BPKAD}

Sesuai dengan Peraturan Daerah Kota Bekasi Nomor 05 Tahun 2010 tentang Perubahan Atas Peraturan Daerah Kota Bekasi Nomor 05 Tahun 2008 tentang Lembaga Teknis Daerah Kota Bekasi (Lembaran Daerah Tahun 2008 Nomor 5 Seri D) bahwa Badan Pengelolaan Keuangan dan Aset Daerah (BPKAD) Kota Bekasi merupakan Lembaga Teknis Daerah yaitu SKPD yang melaksanakan fungsi utama selaku unsur pendukung tugas Walikota dalam penyusunan dan pelaksanaan kebijakan teknis yang bersifat spesifik dalam hal ini mempunyai tugas pokok melaksanakan penyusunan dan melaksanaan kebijakan daerah di bidang anggaran, perbendaharaan, akuntansi dan aset daerah.

Berdasarkan Keputusan Walikota Bekasi Nomor 900/Kep.234-BPKAD/VI/2011 tentang Pelimpahan Kewenangan Pengelolaan Keuangan, Pendapatan dan Barang Daerah bahwa Kepala BPKAD Kota Bekasi diberikan kewenangan selaku Pejabat Pengelola Keuangan Daerah serta bertindak selaku Bendahara Umum Daerah (BUD) yang memiliki kewenangan dalam hal Penyusunan Kebijakan keuangan daerah, Penyusunan APBD, melaksanakan fungsi Bendahara Umum Daerah, Melaksanakan Sistem Akuntansi dan Pelaporan Keuangan Daerah serta Melaksanakan pengelolaan Barang Milik Daerah.

Sejak pemisahan kelembagaan dari Dinas Pendapatan, Pengelolaan Keuangan dan Aset Daerah (DPPKAD) Kota Bekasi menjadi BPKAD Kota Bekasi dan Dinas Pendapatan Daerah Kota Bekasi, BPKAD Kota Bekasi memegang kendali penuh terhadap pengelolaan keuangan dan aset Kota Bekasi khususnya dalam pengelolaan anggaran, belanja daerah serta aset daerah Kota Bekasi. 


\subsubsection{Visi dan misi BPKAD}

BPKAD Kota Bekasi menetapkan Visi Badan untuk Tahun 2013-2018 yaitu “ Pengelolaan Keuangan dan Aset Daerah Yang Akuntabel Menuju Opini Laporan Keuangan WTP “.

Visi tersebut bermakna bahwa semua aktivitas dan kegiatan yang menggunakan uang publik harus akurat, tepat waktu dan dapat dipertanggungjawabkan kepada seluruh stake holders (DPRD, masyarakat luas dan lainnya), dengan mempertimbangkan aspek legalitas dan pengelolaannya (stewardship) untuk menghasilkan sebuah Laporan Keuangan yang akuntabel, tepat waktu, dan meraih Opini Wajar Tanpa Pengecualian (WTP) atas pemeriksaan Badan Pemeriksa Keuangan (BPK) Republik Indonesia.

Untuk merealisasikan Visi BPPKAD maka misi yang akan dilaksanakan adalah sebagai berikut:

1. Mewujudkan Pelayanan Prima Penatausahaan Perkantoran.

2. Mewujudkan Pengelolaan keuangan yang profesional.

3. Terwujudnya opini WTP dalam pengelolaan keuangan daerah.

4. Mewujudkan daya guna aset, prasarana dan sarana penunjang pembangunan daerah.

\section{Program dan Kegiatan}

BPKAD Kota Bekasi diharapkan berperan dalam pencapaian Misi Pemerintah Kota Bekasi yaitu "Menyelenggarakan Tata Kelola Kepemerintahan Yang Baik“ dan mengacu kepada Program Pengelolaan Otonomi Daerah, Pemerintahan Umum, Administrasi Keuangan Daerah, Perangkat Daerah dan Kepegawaian yang memuat Program:

- Peningkatan Prasarana, Sarana dan Alat Kerja Aparatur;

- Peningkatan Pengelolaan Keuangan Daerah;

- Pengelolaan Inventarisasi Aset;dan

- Pengawasan Internal Penggunaan Keuangan Daerah. 
Selanjutnya Perwal No. 39 Tahun 2010 menjelaskan tentang tugas, fungsi dan tata kerja serta rincian tugas jabatan pada BPKAD. Tugas pokok dan fungsi BPKAD Kota Bekasi yaitu membantu mengendalikan dan mengkoordinasi perumusan kebijakan teknis dan pelaksanaan urusan pemerintah yang menjadi kewenangan badan yang meliputi mutasi aset dan inventarisasi serta pemanfaatan dan pemberdayaan aset. Rincian tugas BPKAD antara lain:

a. Melaksanakan pengumpulan dan penyusunan bahan kebijakan umum dan teknis rencana kebutuhan aset daerah. penelitian dan pengkajian kebutuhan barang sebagai dasar pelaksanaan pengadaan barang, mengikuti pelaksanaan pelelangan barang dan bangunan, pelaksanaan administrasi barang daerah, penilaian dan penyusutan aset daerah, pencatatan barang milik daerah, inventarisasi data aset daerah, penyimpanan seluruh bukti asli kepemilikan kekayaan daerah serta pelaksanaan sensus barang milik daerah setiap 5 (lima) tahun sekali dan

b. Melaksanakan penyusunan pedoman petunjuk teknis pemanfaatan dan pengendalian kekayaan daerah, evaluasi daftar hasil pengadaan barang daerah, pemantauan dan pengawasan kepemilikan aset daerah serta dokumentasi kepemilikan aset berupa kendaraan, tanah dan bangunan.

\subsection{Penertiban Barang Milik Daerah}

Penertiban barang milik negara dilakukan Pemerintah Kota Bekasi secara berkesinambungan dengan berusaha membenahi dan memenuhi standar penyajian laporan keuangan

\subsubsection{Latar Belakang Penertiban Barang Milik Daerah}

Pembenahan kualitas laporan keuangan dilakukan karena Pemerintah Kota Bekasi pada tahun 2009 mendapat opini "Disclaimer". Penilaian ini merupakan hasil audit ulang, terhadap penilaian yang dilakukan BPK Jawa Barat sebelumnya, dengan opini Wajar Tanpa Pengecualian (WTP). Setelah terbongkarnya kasus suap pejabat BPK Jawa Barat sebesar Rp 200 juta, seluruh hasil audit kota dan kabupaten di Jawa Barat ditinjau ulang oleh BPK Pusat. Laporan keuangan Kota Bekasi menjadi prioritas audit ulang. Dengan Opini "Disclaimer" memperlihatkan penyajian laporan keuangan Pemerintah Kota Bekasi “jelak".

Pemerintah Kota Bekasi dalam hal ini pelaksana harian Sekretaris Daerah Kota Bekasi, Bapak Dudy Setiabudhi, secara langsung menanggapi opini tersebut 
dengan melakukan pemeriksaan ulang seluruh transaksi selama periode tersebut. Pemeriksaan untuk mencari penyebab selisih sisa pembiayaan anggaran atau silpa sebesar Rp 4,7 miliar. Temuan BPK sisa pembiayaan sebesar Rp. 111 miliar sedang Pemerintah Kota Bekasi melaporkan sebesar Rp. 106 miliar.

Periode selanjutnya laporan keuangan tahun 2010 sampai dengan tahun 2014 Pemerintah Kota Bekasi mendapat opini "Wajar Dengan Pengecualian" dengan catatan pengecualian terhadap manajemen pengelolaan aset daerah 47,06\% tahun 2010 terkait pengelolaan (1) Penatausahaan aset prasarana, sarana dan utilitas (PSU/fasos, fasum) (2) Aset tetap dan (3) investasi non permanen.

Permasalahan yang masih ditemui dalam menjalankan tugas dan fungsi BPKAD Kota Bekasi sebagai lembaga teknis daerah yang menjalankan pengelolaan keuangan dan aset Pemerintah Kota Bekasi sbb:

a. Masih banyaknya kendala dalam Pensertifikatan Aset berupa lahan milik Pemerintah Kota Bekasi;

b. Masih lemahnya sinergitas dalam proses penerbitan rekomendasi lahan Fasos/Fasum;

c. Masih rendahnya kesadaran penyewa lahan fasos/fasum terhadap kewajiban dalam membayar retribusi;

d. Belum optimal pengamanan aset secara administratif maupun penguasaan fisik.

e. Perlu adanya pembaharuan peraturan tentang pemanfaatan lahan fasos sesuai dengan peraturan yang berlaku;

f. Belum optimalnya akurasi data aset pada tiap-tiap SKPD;

g. Masih belum optimalnya komitmen pengelolaan barang di SKPD;

h. Masih terdapatnya kendaraan bermotor yang sudah tidak efektif dan efisien untuk operasional perlu dihapuskan.

\subsubsection{TUJUAN DAN SASARAN RENCANA KERJA BPKAD KOTA BEKASI}

Perumusan tujuan dan sasaran renca kerja BPKAD Kota Bekasi tidak terlepas dari fungsi BPKAD Kota Bekasi, rumusan Renstra BPKAD Kota Bekasi serta rumusan RPJMD Kota Bekasi dapat disajikan pada bagan berikut:

Gambar 4.1 
PERUMUSAN TUJUAN DAN SASARAN RENJA BPKAD KOTA BEKASI

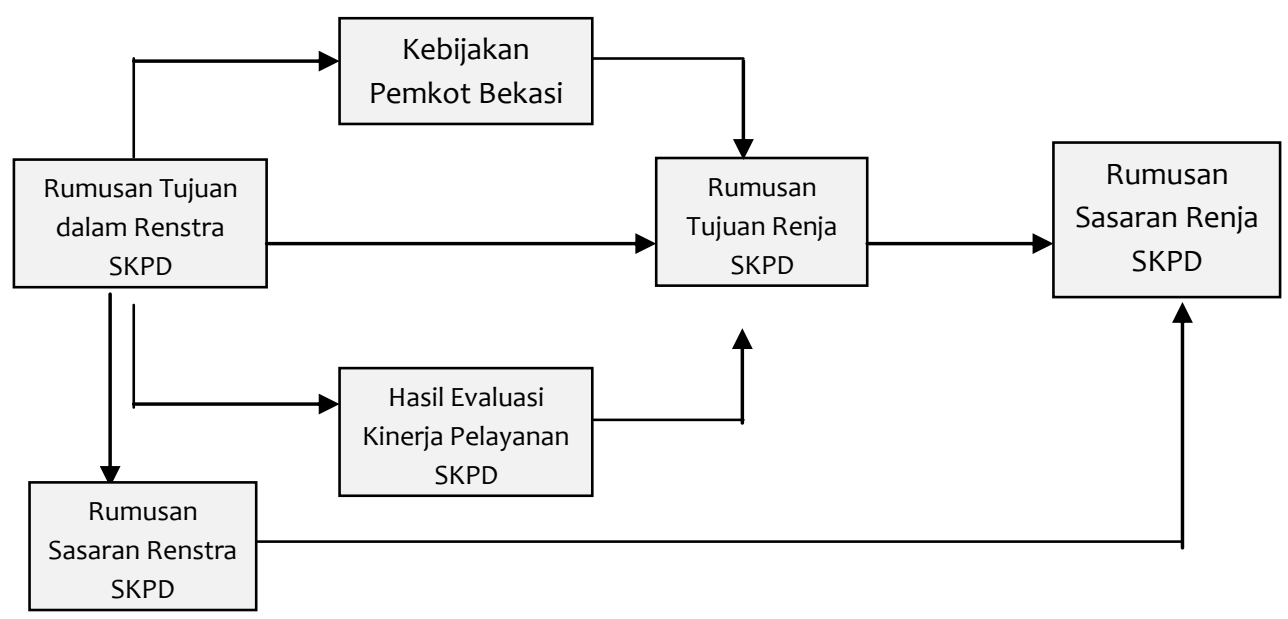

Sumber: Badan Pengelola Keuangan Dan Aset Daerah Kota Bekasi

Dapat dijelaskan pada gambar diatas bahwa rumusan tujuan renca kerja dipengaruhi oleh rumusan tujuan dalam rencana strategis, hasil evaluasi kinerja pelayanan dan kebijakan Pemkot Bekasi. Kemudian Hasil rumusan tujuan rencana kerja akan diturunkan menjadi rumusan sasaran rencana kerja yang akan disinergikan dengan rumusan sasaran rencana strategis.

\subsection{Strategi Dan Arah Kebijakan Manajemen Aset}

Secara jelas tujuan dan sasaran program-program dari Walikota Bekasi sebagai Kepala Daerah tertuang dalam Rencana Pembangunan Jangka Menengah Daerah (RPJMD) Kota Bekasi periode 2013 - 2018 yang terdiri dari 6 Sasaran antara lain :

1. Terwujudnya Tata Kelola Pemerintahan Yang Baik;

2. Terwujudnya Ketersediaan Prasarana dan Sarana Kota Yang Merata Bagi Seluruh Warga;

3. Terwujudnya Kehidupan Warga Yang Dinamis, Inovatif, Kreatif dan Berperan Aktif Dalam Pembangunan;

4. Mewujudkan Pemenuhan Kehidupan Dasar Pendidikan dan Kesehatan;

5. Terpenuhinya kebutuhan lapangan kerja dan kesempatan berusaha;

6. Mewujudkan kedisiplinan, ketertiban sosial, keteladanan dan kehidupan beragama yang kondusif dan terpelihara. 
Dari 6 Sasaran RPJMD Kota Bekasi tersebut terdapat 1 (satu) sasaran yang memuat Indikator Kinerja BPKAD Kota Bekasi yaitu “ Terwujudnya Tata Kelola Kepemerintahan Yang Baik “. Sararan tersebut berkaitan dengan tugas dan fungsi BPKAD Kota Bekasi yang sangat berperan dalam pencapaian Opini BPK terhadap akuntabilitas keuangan Kota Bekasi. BPKAD Kota Bekasi adalah SKPD yang menjadi leading sektor dalam proses pengelolaan keuangan dan aset daerah pada Pemerintahan Kota Bekasi yang bersumber dari APBD. Walaupun tidak dapat dipungkiri bahwa kinerja dan tanggungjawab ini melibatkan seluruh SKPD di wilayah Pemerintah Kota Bekasi.

\subsubsection{Analisis SWOT}

Berdasarkan laporan penyelenggaraan pemerintahan daerah (LPPD) BKPAD Pemerintah Kota Bekasi, berdasarkan hasil analisis SWOT, maka dapat dihasilkan strategi utama BPKAD Kota Bekasi yaitu berupa "Strategis Integrative". Yaitu strategi untuk memaksimalkan peluang dengan meminimkan kelemahan, strategi ini terumuskan berdasarkan Sistem Manajemen Perencanaan Stategis (SMPS) yang mana di kelembagaan BPKAD masih banyak kelemahannya tetapi kelemahan tersebut diminimalisir dengan memanfaatkan peluang yang ada. Strategi Utama dapat dilihat dalam Gambar di bawah ini.

\section{Strategi BPKAD Kota Bekasi}

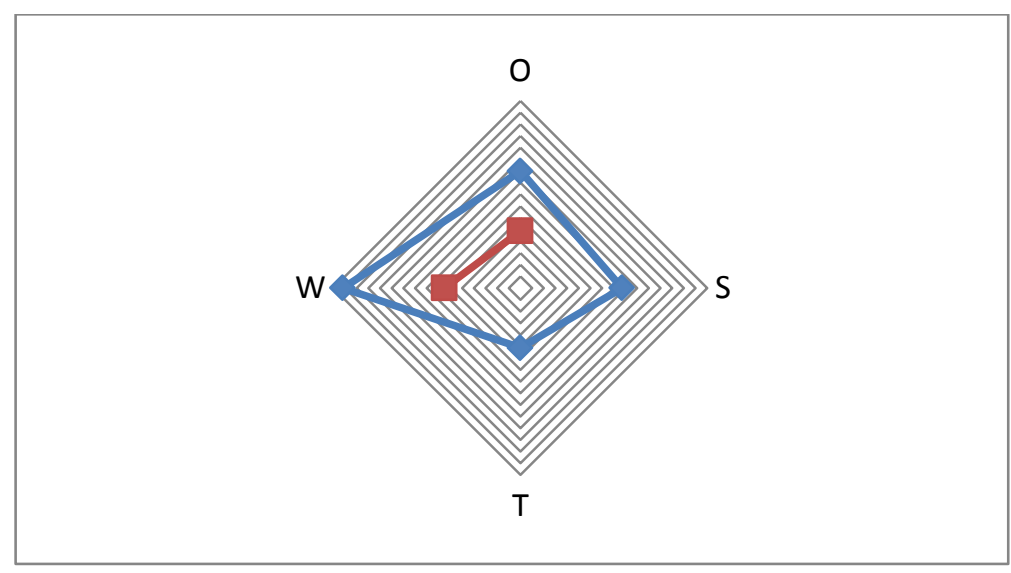

Sumber: LPPD BPKAD tahun 2013

Berdasarkan "Strategi Integrative" BPKAD merencanakan strategi yang mengalami kesenjangan, dengan menumbuhkan peluang melalui perencanaan dan 
sasaran baru. Penetapan strategi rencana kinerja BPKAD diuraikan pada tabel berikut:

\section{Strategi Rencana Kinerja BPKAD Kota Bekasi}

\begin{tabular}{|c|l|l|l|}
\hline NO & \multicolumn{1}{|c|}{ TUJUAN } & \multicolumn{1}{c|}{ SASARAN } & \multicolumn{1}{c|}{ STRATEGI } \\
\hline 1 & $\begin{array}{l}\text { Terwujudnya } \\
\text { Profesionalisme } \\
\text { Manajemen pelayanan } \\
\text { penatausahaan perkantoran }\end{array}$ & $\begin{array}{l}\text { Meningkatkan pelayanan } \\
\text { administrasi perkantoran, } \\
\text { kedisiplinan, profesionalisme } \\
\text { dan transfaransi kinerja } \\
\text { aparatur }\end{array}$ & $\begin{array}{l}\text { Peningkatan kinerja aparatur, } \\
\text { pemanfaatan sarana dan } \\
\text { prasarana aparatur, disiplin } \\
\text { aparatur, kualitas aparatur dan } \\
\text { tranfarasi kinerja aparatur }\end{array}$ \\
\hline 2 & $\begin{array}{l}\text { Terwujudnya pengelolaan } \\
\text { keuangan yang } \\
\text { professional }\end{array}$ & $\begin{array}{l}\text { Meningkatnya } \\
\text { profesionalisme Manajemen } \\
\text { pengelolaan keuangan daerah }\end{array}$ & $\begin{array}{l}\text { Peningkatan pengelolaan } \\
\text { keuangan daerah }\end{array}$ \\
\hline 3 & $\begin{array}{l}\text { Talam pengelolaan } \\
\text { keuangan daerah }\end{array}$ & $\begin{array}{l}\text { Meningkatnya keakuratan } \\
\text { dan ketepatan waktu laporan } \\
\text { keuangan Pemda }\end{array}$ & $\begin{array}{l}\text { Peningkatan pengelolaan } \\
\text { keuangan daerah }\end{array}$ \\
\hline $\begin{array}{l}\text { ket yang optimal guna } \\
\text { peningkatan pembangunan }\end{array}$ & $\begin{array}{l}\text { Meningkatnya pengelolaan } \\
\text { aset daerah }\end{array}$ & $\begin{array}{l}\text { Peningkatan pengelolaan aset } \\
\text { daerah }\end{array}$ \\
\hline
\end{tabular}

Dalam pelaksanaan misi-misi tersebut, BPKAD merumuskan tujuan dan sasaran. Capaian indikator kinerja sasaran stratejik BPKAD Kota Bekasi tahun 2009 sampai dengan 2015 secara keseluruhan sebesar 89,15\%. Realisasi capaian sasaran dari ke 4 ( empat ) misi tersebut adalah sebagai berikut :

\begin{tabular}{|c|c|c|c|c|c|c|c|c|}
\hline $\mathrm{N}$ & Uraian & 2009 & 2010 & 2011 & 2012 & 2013 & 2014 & 2015 \\
\hline & Misi I & & & & & & & \\
\hline 1 & $\begin{array}{l}\text { Tepat waktu dan sasaran dalam } \\
\text { peningkatan } \\
\text { administrasi perkantoran }\end{array}$ & 11 & 16,70 & 23,30 & 75 & 100 & 100 & 100 \\
\hline 2 & $\begin{array}{l}\text { Kebutuhan dan pemeliharaan } \\
\text { sarana dan prasarana aparatur per } \\
\text { tahun terpenuhi }\end{array}$ & 22 & 58,60 & 60,00 & 83,24 & 100 & 100 & 100 \\
\hline 3 & $\begin{array}{l}\text { Aparatur yang profesional dan } \\
\text { sesuai dengan kompetensinya }\end{array}$ & & & & & 100 & 100 & 100 \\
\hline 5 & $\begin{array}{l}\text { Tersusunnya dokumen } \\
\text { perencanaan dan laporan keu }\end{array}$ & & & & & 80 & 95,38 & 96,92 \\
\hline
\end{tabular}




\begin{tabular}{|c|c|c|c|c|c|c|c|c|}
\hline & Misi II & & & & & & & \\
\hline 1 & $\begin{array}{l}\text { Berkurangnya nilai pinjaman } \\
\text { Pemerintah Daerah }\end{array}$ & & & & & 100 & 100 & 100 \\
\hline \multirow[t]{2}{*}{2} & Evaluasi RAPBD Kota & & & & & 80 & & \\
\hline & Misi III & & & & & & & \\
\hline \multirow[t]{2}{*}{1} & $\begin{array}{l}\text { Opini Terhadap Laporan } \\
\text { Keuangan Daerah }\end{array}$ & $\begin{array}{l}\text { Disclai } \\
\text { mer }\end{array}$ & WDP & WDP & WDP & WDP & WDP & WTP \\
\hline & Misi IV & & & & & & & \\
\hline 1 & Luas Lahan Bersertifikat & 32,69 & 35,33 & 35,91 & 35,91 & 35,91 & & \\
\hline \multirow[t]{3}{*}{2} & $\begin{array}{l}\text { Pengelolaan Aset Milik Pemkot } \\
\text { Bekasi }\end{array}$ & & & & & & & \\
\hline & $\begin{array}{l}\text { a. Jumlah SKPD yang sudah tertib } \\
\text { administrasi }\end{array}$ & 11 & 16,70 & 23,40 & 75 & 89,53 & & \\
\hline & $\begin{array}{l}\text { b. Tersedianya Sarana dan } \\
\text { Prasarana Aparatur }\end{array}$ & 22 & 58,60 & 60 & 83,24 & 75,79 & & \\
\hline
\end{tabular}

\section{KESIMPULAN DAN SARAN}

\subsection{Kesimpulan}

Berdasarkan pembahasan yang dilakukan, dapat disimpulkan hal berikut:

1. Inventarisasi aset dilakukan terhadap seluruh BMD yang berada dalam penguasaan Pemerintah Kota Bekasi. Dengan mendata awal seluruh BMD, kemudian mengecek kesesuaian data administratif dengan kondisi fisik BMD. Hal ini dilakukan untuk mengetahui keberadaan, jumlah, kondisi, dan pengkodean BMD yang dikuasai kuasa pengguna barang, serta kesesuaiannya dengan pembukuan BMD.

2. a. Inventarisasi dan Penilaian BMD dilakukan dalam rangka meningkatkan kualitas laporan keuangan Pemerintah Kota Bekasi yang pada tahun 2009 dinyatakan discliamer oleh BPK.

b. Inventarisasi dan Penilaian BMD sebagian besar telah diselesaikan pada tahun 2014, yaitu 98\% dari keseluruhan satuan kerja yang menjadi objek 
inventarisasi dan penilaian BMD. Pelaksanaan Inventarisasi dan Penilaian

BMD ini menurut BPK telah menjadi salah satu faktor yang meningkatkan kualitas laporan keuangan Pemerintah Kota Bekasi tahun 2015, yang ditandai dengan peningkatan opini BPK menjadi WTP

\subsection{Saran}

Berdasarkan hasil penelitian yang telah dilakukan, penulis berupaya memberikan saran dan rekomendasi, sebagai berikut:

1. Berdasarkan hasil penertiban BMD, terdapat tanah fasum/fasos yang belum disertifikasi yang dikhawatirkan disalah fungsikan, sehingga harus segera ditindaklanjuti.

2. Masih terdapat BMD yang tercatat tetapi tidak ditemukan fisiknya, sebab hilang atau perubahan pencatatan menjadi double entry yang harus ditindaklanjuti.

\section{Daftar Pustaka}

http://www.djkn.kemenkeu.go.id Peraturan Pemerintah No. 27 Tahun 2014 Pengelolaan Barang Milik Negara/Daerah

http://kbbi.web.id

Pemerintah Kota Bekasi BPKAD, Laporan Penyelenggaraan Pemerintahan Daerah Pemerintah Kota Bekasi BPKAD, Rencama Kerja (Renja) BPKAD Kota Bekasi Pemerintah Kota Bekasi BPKAD, Rencana Strategis (Renstra BPKAD Kota Bekasi Undang-Undang Otonomi Daerah, UU No.32 Tahun 2004 Tentang Pemerintah Daerah, Penerbit Permata Press

www.ksap.org/sap/id_ID/standar-akuntansi-pemerintahan No. 71 Tahun 2010 Standar Akuntansi Pemerintahan 